\title{
The sodium and potassium intake of 3 to 5 year olds
}

\author{
M E ALLISON AND V WALKER
}

Department of Chemical Pathology and Human Metabolism, Southampton University Medical School

SUMMARY The sodium intake of preschool children in their home environment was investigated and the major sources of sodium other than added table salt identified. Thirty five children from a Southampton general practice were studied. Twenty four hour urinary sodium excretion was measured as a reliable indicator of daily total sodium intake. The daily intake of sodium other than that from added table salt, and of potassium and other nutrients, was also calculated from three day dietary diaries collected using the household measures method. Median excretion of sodium was $62 \mathrm{mmol} / 24 \mathrm{~h}$ (range 28-105, 28 urine collections) and of potassium was $25 \mathrm{mmol} /$ $24 \mathrm{~h}$ (range 14-46). The sodium:potassium ratio was $2 \cdot 7(1 \cdot 4-5 \cdot 2)$. From the diaries, the average daily intake of sodium was $68 \mathrm{mmol}(32-98)$ and of potassium was $47 \mathrm{mmol}(24-95)$, and the sodium:potassium ratio was $1.4(0 \cdot 5-2 \cdot 7)$ (median and ranges, 35 children). Foods contributing more than $30 \mathrm{mmol}$ sodium to one day's intake were mainly processed convenience foods.

The processes that lead to essential hypertension in adults are still not clear, but there is considerable evidence to support an interaction between genetic and environmental factors in determining blood pressure and occurrence of hypertension. ${ }^{12}$ There are data to suggest some consistency of rank order of blood pressure during childhood from as early as 4 years of age, ${ }^{34}$ and the idea has developed that essential hypertension is a process that starts early in life. If this is so, prevention may be possible through control of environmental factors in childhood. ${ }^{1}$

Excessive sodium consumption ${ }^{5}$ or a diet low in potassium relative to sodium ${ }^{6}$ have been incriminated as causative factors. Although neither has been proved definitely, recent nutritional guidelines for the United Kingdom recommend reduction in sodium intake that is thought to be needlessly high. ${ }^{78}$ A World Health Organisation study group similarly recommended moderate reduction of the sodium intake of children. ${ }^{1}$ A high sodium intake in early life may condition children to a lifelong high salt appetite. ${ }^{9}$ In view of all the recent interest, it is surprising how little is known about the sodium consumption of young children in this country. Twelve Australian children aged 3-5 years had seemingly high sodium intakes, probably mainly from processed foods. ${ }^{10}$

This study aimed to evaluate the sodium intake of healthy 3-5 year olds living at home in Hampshire and to identify the major sources of dietary sodium other than added table salt.

\section{Methods}

Total sodium intake was assessed from 24 hour urinary sodium excretion. Dietary diaries obtained using the household measures method ${ }^{11}$ were used to indicate the main food sources of sodium: quantities of foods eaten are described in terms of household measures such as cups or spoons. These are calibrated by the investigator and quantities converted to weights. To minimise the risk that salt consumption would change for the study, a preweighed salt shaker was not provided, and salt added during cooking was not quantified. An interest in dietary sodium was not mentioned to the mothers.

Fifty eight mothers with children aged 3-5 identified from the age and sex register of a Southampton general practice were invited to participate in a general study of children's diets. Mothers who agreed were visited at home during the period December 1984 to March 1985. They were asked to record details of all foods and drinks consumed by their child for three days, including one weekend day, and on one of the days to collect a 24 hour urine sample. At follow up visits details of the diaries were clarified, including the brands of foods, the volumes of utensils used were measured, and the children's heights and weights recorded. Food amounts recorded as volumes in the diaries were converted to the appropriate weights using tables of different foodstuff density. Foods were analysed for 28 
nutrients using a computerised version of the McCance and Widdowson food composition tables ${ }^{12}$ supplemented by values for British cooked dishes. ${ }^{13}$ Totals for each day, and a three day mean, were calculated.

Urinary creatinine concentration was measured by a modified Jaffe reaction, using an LKB Reaction Rate Analyser (LKB Instruments Ltd, Surrey, England) and sodium and potassium concentrations with an ion selective electrode (Beckman Astra 8, Beckman Instruments Inc, California, USA). Urine samples collected for less than 21 hours were excluded, as were those with inappropriately low content of creatinine concentration. Electrolyte excretion of the remainder was adjusted to 24 hours. The Mann Whitney test and linear regression were used for statistical evaluation. The study had the approval of the local ethical committee.

\section{Results}

Thirty five children participated (a response rate of $60 \%$ ) (Table 1). Two children achieved their sixth birthdays during the study. Most were within the expected range of weight for age and sex; five (14\%) were below the 25 th centile and $16(46 \%)$ above the 75 th centile, including five $(14 \%)$ greater than the 97th centile. Quetelet's index (weight $(\mathrm{kg}) / \mathrm{height}$ $\left(\mathrm{m}^{2}\right)$ ) was used as an index of obesity. ${ }^{14}$ When calculated using the rather unusual formula used in the DHSS survey in 1967-68: ${ }^{15}$

$$
\frac{\text { Weight }(\mathrm{kg})}{\text { Height }\left(\mathrm{cm}^{2}\right)} \times 1000
$$

mean values of 1.66 and 1.69 were similar to that of 1.6 found for $3.5-4.5$ year olds in the survey. The

Table 1 Details of 35 children studied. Values are means (ranges)

\begin{tabular}{|c|c|c|c|}
\hline & & Boys & Girls \\
\hline \multicolumn{2}{|l|}{ No } & 19 & 16 \\
\hline \multicolumn{2}{|l|}{ Age (years) } & $4 \cdot 5(3 \cdot 2-6 \cdot 0)$ & $4 \cdot 6(3 \cdot 5-6 \cdot 2)$ \\
\hline \multicolumn{2}{|l|}{ Weight (kg) } & $19(13 \cdot 5-26 \cdot 5)$ & $20(14 \cdot 5-33 \cdot 0)$ \\
\hline \multicolumn{2}{|l|}{ Height $(\mathrm{cm})$} & $106(95 \cdot 5-115)$ & $107(98 \cdot 5-123)$ \\
\hline \multicolumn{2}{|c|}{ Surface area $\left(\mathrm{m}^{2}\right)$} & $0.73(0.58-0.90)$ & $0.75(0.62-1.03)$ \\
\hline \multicolumn{2}{|c|}{ Quetelet's index $\left(\mathrm{kg} / \mathrm{m}^{2}\right)$} & $16 \cdot 6(13 \cdot 8-20 \cdot 1)$ & $16 \cdot 9(14 \cdot 8-21 \cdot 8)$ \\
\hline & & All children & \\
\hline \multirow[t]{6}{*}{ Social class } & I & 2 & \\
\hline & II & 8 & \\
\hline & III & 16 & \\
\hline & IV & 4 & \\
\hline & V & 1 & \\
\hline & $\mathrm{UE}^{*}$ & 4 & \\
\hline
\end{tabular}

\footnotetext{
${ }^{*}$ Father unemployed
}

families were drawn from all social classes, with most from classes II and III.

Results from the urine collections (Table 2). Thirty one timed urine samples were obtained. Four children were uncooperative, ill, or incontinent. Three samples were rejected as being incomplete collections. The range of collection times of the remaining 28 samples was 21 to 25 hours, 24 being collected to within half an hour of 24 hours. The 24 hour sodium excretion for 15 boys (mean $67 \mathrm{mmol}$, range 52-95) and 13 girls (mean $63 \mathrm{mmol}$, range 28-105) did not differ significantly (Mann-Whitney test), and so the results for both sexes were combined. Sodium excretion was not correlated significantly with age, body weight, or obesity. The median values for sodium excretion of the small groups of children in each social class were similar.

Results from food table analysis of the dietary records. All the mothers completed the diaries, 31 for three days and four for two days. An average intake of each nutrient was calculated for each child (Table 3). The overall mean energy intake was $89 \%$ of the relevant recommended dietary allowances for age and sex. ${ }^{16}$ The mean contributions of protein, fat, and carbohydrate to total energy intake were

Table 2 Results of urinary analysis of 28 samples corrected to 24 hours

\begin{tabular}{lccc}
\hline Excretion per 24 hours & Mean & Median & $\begin{array}{l}\text { Observed } \\
\text { range }\end{array}$ \\
\hline Volume $(\mathrm{ml})$ & 581 & 543 & $273-1023$ \\
Sodium $(\mathrm{mmol})$ & 65 & 62 & $28-105$ \\
Sodium $(\mathrm{mmol} / \mathrm{kg}$ body weight) & $3 \cdot 5$ & $3 \cdot 5$ & $1 \cdot 6-6 \cdot 2$ \\
Sodium $\left(\mathrm{mmol} / \mathrm{m}^{2}\right)$ & 90 & 88 & $42-154$ \\
Potassium $(\mathrm{mmol})$ & 24 & 25 & $14-46$ \\
Sodium:potassium ratio & $2 \cdot 8$ & $2 \cdot 7$ & $1 \cdot 4-5 \cdot 2$ \\
Creatinine $(\mu \mathrm{mol} / \mathrm{kg})$ & 146 & 149 & $77-206$ \\
\hline
\end{tabular}

Table 3 Results from food table analysis of the dietary records of the 35 children studied

\begin{tabular}{|c|c|c|c|}
\hline & \multicolumn{3}{|c|}{ Daily intake } \\
\hline & Mean & Median & $\begin{array}{l}\text { Observed } \\
\text { range }\end{array}$ \\
\hline Sodium (mmol) & 69 & 68 & $32-98$ \\
\hline Potassium (mmol) & 50 & 47 & $24-95$ \\
\hline Sodium: potassium ratio & 1.5 & 1.4 & $0.5-2 \cdot 7$ \\
\hline Energy (kcal) & 1455 & 1388 & $787-2204$ \\
\hline Protein $(\mathrm{g})$ & 46 & 45 & $28-60$ \\
\hline As \% of $\mathrm{kcal}$ & $12 \cdot 7$ & & $9-17$ \\
\hline Fat $(\mathrm{g})$ & 59 & 54 & $27-91$ \\
\hline As $\%$ of $\mathrm{kcal}$ & 36 & & $26-46$ \\
\hline Carbohydrate (g) & 186 & 181 & $114-287$ \\
\hline As $\%$ of kcal & 51 & & $38-60$ \\
\hline
\end{tabular}


similar to contributions of $11.5 \%, 38 \%$, and $50.5 \%$, respectively, found for children aged 3.5 to 4.5 years in the UK in $1967-68 .{ }^{15}$ For the children as a group daily sodium intake calculated from the diaries was similar to that estimated more reliably from urinary sodium excretion (Tables 2 and 3). Although the two estimates were significantly correlated $(\mathrm{r}=0 \cdot 4$, $\mathrm{p}<0.05, \mathrm{n}=28$ ), the estimates differed in some individuals. This is to be expected considering the inherent inaccuracies of dietary diary analyses.

A highly significant negative correlation was observed between the ratio of sodium to energy intake $(\mathrm{mmol} / \mathrm{Kcal})$ and age $(\mathrm{r}=-0.63, \mathrm{p}<0.001$, $\mathrm{n}=35)$ and to body weight $(\mathrm{r}=-0.50, \mathrm{p}<0.01$, $n=35)$. Age and weight correlated closely $(r=0 \cdot 69$, $\mathrm{p}<0.001, \mathrm{n}=35)$. This suggests that the young children had proportionately more sodium in their diet than the older children.

Potassium intake and sodium:potassium ratio. In this study the mean potassium intake estimated from the diaries of $50 \mathrm{mmol} / 24 \mathrm{~h}$ (range 24-95) was higher than the mean urinary potassium excretion of 24 $\mathrm{mmol} / 24 \mathrm{~h}$ (range 14-46). This accounts for the lower sodium:potassium ratios calculated from the diaries (mean $1 \cdot 5$, range $0 \cdot 5-2 \cdot 7$ ) when compared with urinary analyses (mean $2 \cdot 8$, range $1 \cdot 4-5 \cdot 2$ ).

Foods contributing most sodium to the daily intake. The total number of days recorded in the diaries was 101. On 17 occasions a single foodstuff contributed more than $30 \mathrm{mmol}$ of sodium in any one day (roughly half the mean daily intake for the group). This represented one helping, or several servings if the foodstuff was consumed more than once during the day, and accounted for $24-88 \%$ of the total

Table 4 Foods contributing more than 30 mmol of sodium in any one day (101 days recorded)

\begin{tabular}{lll}
\hline & $\begin{array}{l}\text { mmol Of } \\
\text { sodium } \\
\text { per day }\end{array}$ & $\begin{array}{l}\text { \% Of day's } \\
\text { sodium } \\
\text { intake }\end{array}$ \\
\hline Chicken soup, cream of, canned & 85 & 88 \\
Chicken noodle soup, dricd & 30 & 24 \\
Faggots & 64 & 49 \\
Faggots & 32 & 28 \\
Faggots & 32 & 33 \\
Beefburgers, fried, frozen & 54 & 53 \\
Beefburgers, fried, frozen & 30 & 44 \\
Spaghetti, in tomato sauce, canned & 43 & 42 \\
Cheese, cheddar & 42 & 37 \\
Cheese, spread & 36 & 36 \\
Bacon gammon joint, boiled & 40 & 37 \\
'All Bran' & 38 & 55 \\
Meat pie & 36 & 68 \\
Baked beans, in tomato sauce, canned & 35 & 51 \\
Baked beans, in tomato sauce, canned & 35 & 30 \\
Baked beans, in tomato sauce, canned & 34 & 47 \\
Sausages, pork, fried & 30 & 36 \\
\hline
\end{tabular}

sodium intake for that day (Table 4). Purchased processed foods were the main contributors, but cheese and a breakfast cereal were also included.

\section{Discussion}

The mean urinary sodium excretion of 28 children aged $3-5$ in this study was $65 \mathrm{mmol} / 24 \mathrm{~h}$ (range 28-105 mmol/24 h) and when related to body weight was $3.5 \mathrm{mmol} / \mathrm{kg} / 24 \mathrm{~h}$ (range $1.6-6.2 \mathrm{mmol} / \mathrm{kg} / 24 \mathrm{~h}$ ). Non-renal losses of sodium in healthy children of this age are $3-4 \mathrm{mmol} / 24 \mathrm{~h},{ }^{17}$ and apart from a small amount incorporated into growing tissues, any surplus sodium absorbed from the diet is excreted in the urine. Urinary sodium therefore reflects intake closely. The findings for our children were similar to those for 12 children aged 3-5 in Australia, whose urinary sodium on their normal diets was 28-121 $\mathrm{mmol} / 24 \mathrm{~h}$, with a mean of $67 \mathrm{mmol} / 24 \mathrm{~h} .{ }^{10}$ For comparison, most adults in the UK are estimated to have an intake of 7-12 $\mathrm{g}$ of sodium chloride, equivalent to $120-205 \mathrm{mmol}$ of sodium. ${ }^{78}$

Are these intakes excessive? Maximum recommended sodium intakes for children are not well established. The estimated safe and adequate daily dietary intake recommended for 4-6 year olds by The National Academy of Sciences USA in 1980 was 20-59 mmol per day. The lower level was based on the average intake of breast fed 6 month old infants $\left(26 \mathrm{mmol} / \mathrm{m}^{2}\right.$ per day) and the suggested upper level was three times this. ${ }^{18}$ Safe tolerance limits for children were estimated rather arbitrarily by the US Academy of Pediatrics to be roughly $8-100 \mathrm{mmol} /$ day, as the minimal requirements are around 8 mmol per day and infants can tolerate $100 \mathrm{mmol} /$ day without adverse effects. ${ }^{19}$ Thus in $17(61 \%)$ of our 28 children sodium intake exceeded the US 1980 recommended allowances, but only one child had an intake above 'safe limits'. We do not have the facts to decide whether intakes of this order are harmful to children with a genetic risk of developing hypertension. An overall target intake for adults of $5 \mathrm{~g}$ sodium chloride per day ( $85 \mathrm{mmol}$ of sodium) was proposed by $\mathrm{WHO}^{20}$ For a $70 \mathrm{~kg}$ adult with a surface area of $1.73 \mathrm{~m}^{2}$ this is $1.2 \mathrm{mmol} / \mathrm{kg}$ per day, or $49 \mathrm{mmol} / \mathrm{m}^{2}$ per day-rather less than the intakes of the children in this study.

Roughly $30 \%$ of the salt intake of adults in the UK is added at table or in cooking. ${ }^{8}$ The close similarity of sodium intakes calculated from the dietary records in this study, which excluded added salt, to the estimates from the urinary sodium, which include sodium from all sources, suggests that added salt makes a relatively smaller contribution to total intake in young children. The major sodium sources without this were identified as mainly processed 
convenience foods such as beefburgers, baked beans, and soups-foods that the general public does not usually consider 'salty'. The children were not exposed to 'take away' foods, and their diets were not atypical in any obvious way. The mothers confirmed the long recognised problems of feeding younger preschool children, and many explained that their children refused the family meals and so were provided with separate 'acceptable' foods, which were generally some kind of processed foodstuffs. This might have accounted for the high sodium to energy intake in the younger children.

There is some evidence that a high potassium intake may protect against the hypertensive effects of sodium, and that exposure to a high sodium/low potassum intake may be a cause of hypertension in susceptible individuals. ${ }^{7}$ There are no guidelines for the optimal dietary sodium:potassium ratio. In genetically salt sensitive rats a ratio of less than $2 \cdot 0$ protects against hypertension. The ratio in human milk is 0.6 to $0 \cdot 7 .{ }^{19}$ In adults the sodium:potassium ratio in urine has been used as an assessment of the dietary ratio. ${ }^{6}$ The results from this study, however, suggest that this might be misleading in childhood, as the ratios calculated from the diaries were lower than those from the urinary analyses. The difference was attributable to the potassium content-median $47 \mathrm{mmol} / 24$ hour from the diaries and $25 \mathrm{mmol} / 24$ hour from the urine. Non-renal losses of potassium might account in part for the discrepancy, but there have been few carefully conducted electrolyte balance studies in healthy young children to provide firm data. On a dietary potassium intake of 2.27 (SD $0 \cdot 80) \mathrm{mmol} / \mathrm{kg}$ per day the urinary potassium excretion of eight healthy children aged 6 months to 8.2 years was $1.36(\mathrm{SD} 0.51) \mathrm{mmol} / \mathrm{kg} / 24 \mathrm{~h}(60 \%$ of the intake) and the faecal loss was 0.19 (SD 0.09) $\mathrm{mmol} / \mathrm{kg} / 24 \mathrm{~h}^{21}$ It is probable too, however, that short comings of the study also contributed to the difference. Collection of a single urine sample did not allow for day to day variations in potassium intake. Moreover, some of the data in the food tables is quite old and may not reflect accurately the potassium content of the modern preschool diet.

There seems little scope for mothers of young children to reduce the sodium intake much below that observed. Omission of table salt will help a little. Low sodium foods are generally expensive and not widely available. After 24 hours on a diet that contained no processed foods, the urinary sodium excretion of five Australian 3-5 year olds fell to 6-46 $\mathrm{mmol} / 24 \mathrm{~h}$ (mean 19). ${ }^{10}$ It seems that the only effective course would be to reduce the sodium added during manufacture of those foods which children like. Sodium salts are used for a variety of purposes in food processing. Sometimes there is not a safe or equally effective alternative, but the necessity for the use of sodium additives for flavouring might be questioned. There is clearly a need to establish definitely whether the amount of sodium consumed in childhood has any relevance to the later development of hypertension. ${ }^{1}$

We thank Dr T Rolles for allowing us access to her patients, Dr M Nelson for advice about dietary assessment, and Janet O'Clarey for help with the food table analysis.

\section{References}

1 World Health Organisation Study Group. Blood pressure studies in children. WHO Technical Report series 1985 no 715 Geneva: WHO, 1985.

2 Szklo M. Epidemiologic patterns of blood pressure in children. Epidemiol Rev 1979;1:143-69.

${ }^{3}$ Zinner SH, Margolius HS, Rosner B, Kass EH. Stability of blood pressure rank and urinary kallikrein concentration in childhood: an eight-year follow-up. Circulation 1978;58:908-15.

4 de Swiet M, Fayers P, Shinebourne EA. Value of repeated blood pressure measurements in children: the Brompton study. Br Med J 1980;280:1567-9.

${ }^{5}$ de Wardener HE. Salt and hypertension. Lancet 1984;ii:688 (letter).

${ }^{6}$ Meneely GR, Battarbee HD. High sodium-low potassium environment and hypertension. Am J Cardiol 1976;38:768-85.

7 National Advisory Committee on Nutrition Education. Proposals for nutritional guidelines for health education in Britain. Lancet 1983;ii:835-7.

${ }^{8}$ Department of Health and Social Security Committee on Medical Aspects of Food Policy. Diet and cardiovascular disease. Report of health and social subjects. no 28 . London: HMSO, 1984.

9 Lauer RM, Clarke WR, Rames LK. Blood pressure in childhood. Postgrad Med J 1978;54:206-10.

10 Miles JM, Miles TS. Effect of processed foods on the salt intake of preschool children. Med J Aust 1982;2:23-5.

11 Nelson M, Nettleton PA. Dietary survey methods-a semiweighed technique for measuring dietary intake within families. Journal of Human Nutrition 1980;34:325-48.

12 Paul AA, Southgate DAT. The composition of foods. London: HMSO (Amsterdam: Elsevier/North Holland), 1978.

${ }^{13}$ Wiles SJ, Nettleton PA. The nutrient composition of some cooked dishes eaten in Britain-a supplementary food composition table. Journal of Human Nutrition 1980;34:189-223.

${ }^{14}$ Khosla T, Lowe CR. Indices of obesity derived from body weight and height. British Journal of Preventive Social Medicine 1967;21:122-8.

15 Department of Health and Social Security. Nutrition survey of preschool children 1967-68. Report on Health and Social Subjects no 10. London: HMSO, 1975.

${ }^{16}$ Department of Health and Social Security Committee on Medical Aspects of Food Policy. Recommended daily amounts of food energy and nutrients for groups of people in the UK. Report on Health and Social Subjects no 15. London: HMSO, 1979.

17 Vaughan VC, McKay RJ, Behrman RE, Nelson WE, eds. Nelson textbook of pediatrics. 1979. Philadelphia: WB Saunders Co, 1979.

${ }^{18}$ Food and Nutrition Board, National Academy of Sciences. Recommended dietary allowances. 9th ed. Washington: National Research Council, 1980:175-8.

19 Holliday MA, chairman, Committee on Nutrition. Salt intake and eating patterns of infants and children in relation to blood pressure. American Academy of Pediatrics 1974;53:115-21. 
${ }^{20}$ World Health Organisation. Primary prevention of essential hypertension. Report of a WHO scientific group. Technical report series 686. Geneva: WHO, 1983.

21 Alexander FW, Clayton BE, Delves HT. Mineral and trace metal balances in children receiving normal and synthetic diets. $Q J$ Med 1974;43:89-111.
Correspondence to Dr V Walker, Department of Chemical Pathology and Human Metabolism, South Laboratory and Path Block, Level D, Southampton General Hospital, Tremona Road, Southampton.

Received 15 October 1985

\section{Fifty years ago}

\section{Reading difficulties in children \\ Mildred Creak (London)-Arch Dis Child 1936;11:143-156}

Fifty children were studied who had been referred for difficulty in school work or were presumed to have such difficulties after interview. There were 38 boys and 12 girls between the ages of 6.3 years and 14.8 years. A variety of tests were given, including matching patterns, copying patterns, reproducing rhythms, and identifying wooden letters and numbers when blindfolded and also identifying them when traced on the back of the hand. Among the older children 'word tests' were used. 'The rhythm test separated out a small group of interesting cases. It was found that out of the fifty children, nine, who showed no difficulty in any other test, failed completely in this one. These were all children of good intelligence, with noticeable hyperkinesis, and with one exception outstandingly late in learning to talk. The association of a failure in auditory memory with retarded speech suggests an auditory factor.' When discussing 'Emotional Aspects' Dr Creak states 'By the time the case reaches the clinic the child has usually been accepted as 'silly' by fellow pupils and backward by his teachers. His grotesque compositions are held up to the class for ridicule. What is perhaps worse is when he is regarded as obstinate and constantly receives reports such as "could do better if he tried and lacks concentration."

(Dr Mildred Creak wrote this paper when she was physician in charge of the Children's Department, Maudsley Hospital, London. I had not read the paper before, which was my loss, as although the understanding of children's learning difficulties has undoubtedly improved among the various disciplines involved, so much of what Dr Creak says rings true today. Her 'subgroup' of children who failed on the 'rhythm test' is of particular interest in view of the recent work of Bradley and Bryant, who studied the hypothesis that children's experiences with rhyme and alliteration, which typically begin some time before they arrive at school, do have an influence on the progress they make in learning how to read and spell during their first years at school. ${ }^{1}$ They found that their rhyming and alliteration scores bore a consistent and significant relation to progress in reading and spelling and that training these children to categorise words by their sounds improved their reading and spelling. This seemed to prove that the difficulties some children have in such learning can be attributed to a failure to master a phonological skill that comes naturally to most. NEIL GORDON.)

\section{Reference}

${ }^{1}$ Bradley L, Bryant P. Rhyme and reason in reading and spelling. Ann Arbor: University of Michigan Press, 1985. 